\title{
Public Policy for Financing the Practice of Physical Education
}

\author{
Irfan $^{*}$, Rusdin, Sri Yanti, Shutan Arie Shandi, Ihsan \\ Sekolah Tinggi Keguruan dan Ilmu Pendidikan (STKIP) Taman Siswa Bima, Indonesia
}

Received August 4, 2020; Revised January 30, 2021; Accepted February 17, 2021

\section{Cite This Paper in the following Citation Styles}

(a): [1] Irfan, Rusdin, Sri Yanti, Shutan Arie Shandi, Ihsan, "Public Policy for Financing the Practice of Physical Education," International Journal of Human Movement and Sports Sciences, Vol. 9, No. 2, pp. 209-218, 2021. DOI: 10.13189/saj.2021.090207.

(b): Irfan, Rusdin, Sri Yanti, Shutan Arie Shandi, Ihsan (2021). Public Policy for Financing the Practice of Physical Education. International Journal of Human Movement and Sports Sciences, 9(2), 209-218. DOI: 10.13189/saj.2021.090207.

Copyright $\mathrm{C} 2021$ by authors, all rights reserved. Authors agree that this article remains permanently open access under the terms of the Creative Commons Attribution License 4.0 International License

\begin{abstract}
Purpose: Analyze government policies regarding the financing of physical education. Design/methodology/approach: This research is a descriptive study using qualitative methods. The research subjects were 32 people. The research analysis is data reduction, data presentation, and conclusion drawing. Findings: (1) the regional budget allocation policy for financing education delivery exceeds the minimum limit of $20 \%$ of the regional revenue and expenditure budget. (2) the operational implementation of physical education in educational units only relies on school operational assistance funds. (3) the education budget allocation is not proportional to the funding of programs to increase the competence of human resources, only $0.3 \%$ is budgeted by the Education Office. The funding for physical education providers is more dominant in the program to improve sports facilities and infrastructure, namely $8 \%$ of the budget for education providers. Originality/value: (1) The education financing policy model needs budget allocation management to increase human resources (internal) to strengthen the competence of technical personnel in various fields in the Education Office in the form of training. (2) Model of budget allocation for human resource development (external), the budget allocated for teacher and student activities in the form of technical guidance and training. The realization of this policy model requires policy intervention in the form of political will with an approach of communication, authority, trust, value.
\end{abstract}

Keywords Financing Policies, Physical Education

\section{Introduction}

An innovative education financing mechanism involves various parties to encourage quality education (Bellinger et al., 2016) [1]. The findings of Antoni V, Clara F, (2016) [2] in their research on education policy contribute to individual goals and educational positions provide collective awareness of social status. The results of the research are similar (Bellei, C., \& Orellana, 2015) [3]. About the main educational actors, and families demand, schools and teachers regarding changes in the goals and work of educational institutions regarding better education governance.

Innovative financing will support the success of the implementation of physical education in Bima, policy support will give great hope for the progress of education, of course through sound bureaucratic governance for education budget allocation as research findings (Ramba \& Nur, 2015) [4], That accountability the bureaucracy which includes responsibility and enforcement in the management of regional budgets not work well in Konawe education in Southeast Sulawesi Province. The accountability of the bureaucracy in the management of regional budgets in education in Konawe, Southeast Sulawesi Province is not based on professional standards and norms of behavior. This is because the bureaucratic officials who manage the Regional Budget operate within the context of patron-client-oriented power relations. The patron-client-oriented power relationship is systematically developed to realize the vested interests that additional income and office continuity. 
Education policy reforms through free education have led to increased access to basic education for many school-age children in Malawi so that the number of enrollments has increased, because it has an impact on the financial needs of education for school-age children in Malawi (Antoni V, Clara F, 2016) [5]. Public policymaking requires a more skilled and smarter approach in deciding policies (Seiter \& Seiter, 2016) [6]. Policy reform aims to build a more transparent system in allocating the budget for education delivery. The amount of budget support from public officials will affect the role of parents in making financial contributions for their children who attend educational units. The results of the study (Herdjiono \& Damanik, 2016) [7] found that financial attitudes have an effect on financial management behavior, while financial knowledge and parents' income have no effect on financial management behavior. This study has two implications, (1) attitude is an important factor in supporting financial behavior, where attitudes are generally influenced by environmental and social interactions, (2) financial knowledge has no effect on financial behavior because financial education is less effective in low-income countries or regions. and medium. (Gilbert \& Ambrose, 2013) [8] stated that the initial stage of the budgeting process in schools is supported by the proportion of schools which indicates that they usually divert funds for attendance at school facility construction projects, resulting in the lack of operational funds for the school itself.

\section{Literature Review}

\subsection{Research Literature}

Public policy implementation is influenced by several factors, including aspects of authority, resources, communication, and disposition. Dimensions that can be used to evaluate the implementation of public policies include consistency, transparency, accountability, fairness, effectiveness, and efficiency. Meanwhile, evaluation of policy implementation needs to be carried out comprehensively, in making innovations and breakthroughs in service to the public, discretion can be made in the implementation of public policies as long as they do not conflict with applicable norms and regulations (Ramdhani \& Ramdhani, 2017) [9]. Research conducted by Syamsulriza (2017) [10] found that the process of organizing physical education in the education unit in Aceh Besar district has been implemented, but has not yet run optimally. This is due to the low level of innovation and creativity of physical education teachers, physical education facilities and infrastructure are not representative and limited, the education budget has not been realized specifically for the implementation of physical education, and in general respondents give a positive response if the government implements public policies for the development of a physical education delivery system. In the education unit.

The literature study on policy implementation from the above research encourages education policies to be transparent, bureaucratic accountable to formulate and implement regulations regarding education financing. Syamsulriza research specifically concerns the implementation of physical education in Aceh Province, all of which are the low levels of innovation and creativity of teachers which affect the facilities and budget support for the implementation of physical education. Sports finance cannot be separated from various problems, financial problems that must be faced by all parties. Finance is the process of examining numbers, determining results, and identifying what happened in the past and future for a company or entity (Fried, Deschricer and Mondello, 2013: 7) [11]. Offering a variety of financing options can help respond to a variety of needs. Governments usually use a variety of mechanisms to fund students and institutions. This program works in different ways and creates incentives (and disincentives) that interactions between them can be problematic, so policymakers need to ensure alignment (World Bank, 2019) [12].

The results of research by Avourdiadou \& Theodorakis (2014), this finding makes a positive contribution to our understanding of how service quality and satisfaction is developed and affects customer retention at different stages of consumption. Good service will provide an advantage in quality in delivery. The results of the same study by (Ndayisenga \& Tomoliyus, 2019) [13] the findings show that there is a significant effect of service quality on satisfaction, the effect of service quality. Although both of these studies are about fitness centers, we can conclude that quality service will generate good public trust; the results of this study can be implemented in services and budget allocation for education. As strong as the state is in allocating the budget for the implementation of physical education, of course, the principal must address it in implementing the budget. Schools must be maximized in allocating budgets for teaching and learning activities and increasing the competence of teachers and students through various training activities and student competitions. The findings reveal that junior high school principals need budget skills for financial management for the implementation of the Universal Basic Education (UBE) program at Ebonyi State Junior High School. Based on the findings, it was recommended, among other things, that the government should organize workshops and seminars for junior high school principals to further update their knowledge of financial management skills. Financial management skills are very important for junior high school principals in Ebonyi Country for the implementation of the UBE program (Nwafukwa, 2015) [14]. 
Ensuring that the budget is optimal for the operational funding of education delivery, especially physical education, of course, requires policies that are truly in favor of improving the quality of education delivery. This is because the amount of the budget allocation must be right on target, for the operation of providing education in the education unit, so that all the needs for carrying out physical education can be met in teaching and learning activities. Seeing these dynamics, of course, financing the implementation of the education system, especially physical education, is not fully the responsibility of the state. However, it is necessary to support the education budget from various stakeholders so that it will be able to raise a collective spirit (mutual cooperation) to build education, if the financing system is integrated from the state and supported by education funds from the community it will strengthen the progress of education delivery, the operational activities of providing education in educational units no longer experience obstacles in terms of financing. This research will focus on how government policies on education finance.

\subsection{Materials and Methods}

The research method used is qualitative research, which means qualitative research to understand the phenomena experienced by research subjects such as behavior, perception, motivation for action, etc., holistically, and by means of descriptions in nature and by utilizing various natural methods (Moleong, 2018) [15]. Design/methodology/approach: This research is a descriptive study using qualitative methods. The subjects of government policy research on the financing of physical education providers in Bima totaled 32 people including the Regent as the regional head of the Bima Regency, the Education Culture Office, the Prov. NTB through the Dikmen Unit in Bima Regency, DPRD Bima Regency Commission IV in the field of education as a control and oversight institution for government performance, the education council as a community institution that has an important role in supervising partners in the delivery of education, as a teacher professional organization. Supervisors are in charge of coaching teachers. The principal of the school is the leader of the organization in the education unit. Sports academics as experts.

\subsection{Procedures of Data Analysis}

Data analysis as a prerequisite for research related to government policies on financing physical education providers. Collecting data is collecting data at the research location by conducting observations, interviews, and documentation by determining the data collection strategy that is deemed appropriate and to determine the focus and data deepening in the subsequent data collection process.
Data reduction, namely as a process of selecting, focusing, abstracting, transforming the rough data in the direct field, and continuing it at the time of data collection, thus data reduction begins when the researcher focuses on the research area. Presentation of data is namely a series of information organizations that enable research to be carried out. The presentation of data is obtained by various types, networks, activity linkages, or tables. Drawing conclusions, namely in data collection, researchers must understand and be responsive to something that is examined directly in the field by compiling directional and causal patterns (Matthew B.Miles and Huberman, 1992) in (Tjetjep, 2014) [16].



Figure 1. Techniques of data analysis (Matthew B. Miles and Huberman) source from Tjetjep 2014

\section{Results}

\subsection{Government Policy on Education Financing}

The results of this study will be analyzed based on what was adopted and modified from Edward's policy theory, that the financing of the education system, particularly sports physical education, is not fully the responsibility of the state. The condition of education in Bima District, NTB Province still needs education budget support from various stakeholders so that later it will be able to generate mutual enthusiasm (mutual cooperation) to build education, thus if the state financing system is supported by education funds from the community it will strengthen education progress in terms of financing needs operational of each educational unit, so that the operational activities of providing education in educational units do not experience obstacles in terms of financing.

The implementation of public official institutions certainly requires a budget as a supporting operation to realize good governance, including educational institutions in the Education Office. The budget in the implementation of education is to finance (cosh) everything related to the implementation of education, both operational costs and other development costs related to the interests of education development. A targeted budget allocation will enable the implementation of education right on target to achieve the full goal of 
education, namely improving the quality of education, however, a large and right-on-target budget allocation actually depends on the alignments and priorities of education development carried out by public officials. Based on the research data that the Regional Assistance Government Budget amounts to Rp. 1,778,713,865,742. This amount is the total amount that has not been allocated to several agencies within the scope of the Bima Regency government, including the budget for the administrators of the Education and Culture Office. The education budget allocation has exceeded the minimum limit mandated by the Law of the Republic of Indonesia Number 20 of 2003 National Education System Article 49 Paragraph 1 that education funds other than teacher salaries and official education costs are allocated a minimum of $20 \%$ of the State Revenue and Expenditure Budget in the education sector and at least $20 \%$ of the Regional Revenue and Expenditure Budget. The education budget allocation at the Education and Culture Office continues to increase from 2016-2018. The amount of the budget in 2016 for the education budget is Rp. $35,588,432,500.00$. In 2017, the education budget continued to increase many times over to $\mathrm{Rp}$. $119,546,843,777.00$. Whereas in 2018 the education budget for Bima Regency was Rp. 174,113,270,000.00.

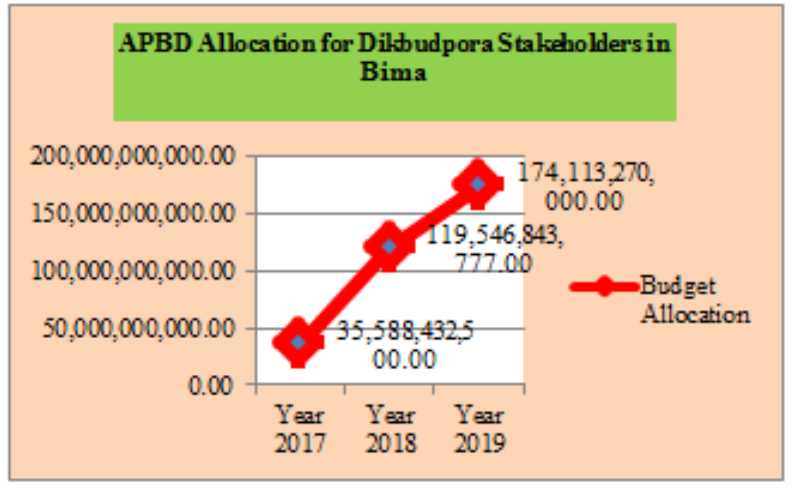

Figure 2. Budget for education takeholders Dikbudpora Bima

At the SMA/SMK level, the budget allocation for education through the NTB Provincial DIKBUD through the UPT Dikmen Services and PK-PLK Bima, in 2017 the education budget allocation Rp. 1,248,040,438. In 2018 the education budget allocation was IDR 1,176,474,604. Whereas in 2019 the education budget allocation was IDR $1,245,448,249$. This is in accordance with Law 23 of 2014 concerning regional government; the affairs of SMA and SMK are transferred to the authority of the Province. Furthermore, regarding education funding, the regional government issued West Nusa Tenggara Provincial regulation number 7 of 2018 concerning Amendments to Regional Regulation Number 4 of 2015 concerning the implementation of education article 39 regional governments can allocate education funds for operational and personal costs that are not financed by the APBN.

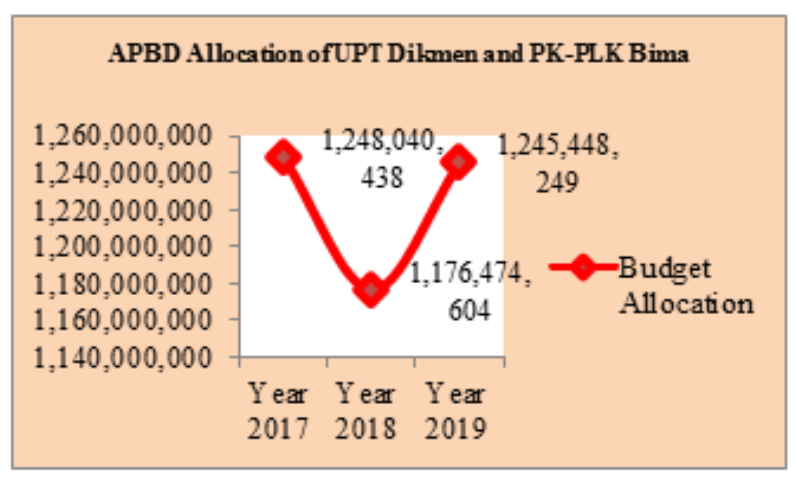

Figure 3. Budget of education stakeholders UPT Dikmen Bima

The implementation of public official institutions certainly requires a budget as a supporting operation to realize good governance, including educational institutions in the Education Office. The budget in the implementation of education is to finance (cosh) everything related to the implementation of education, both operational costs and other development costs related to the interests of education development itself. A targeted budget allocation will enable the implementation of education right on target to achieve complete educational goals, namely the intellectual life of the nation, however, a large and well-targeted budget allocation actually depends on the alignments and priorities of education development carried out by public officials.

\subsection{Use of School Operational Assistance Funds (BOS)}

The budget allocation that has been determined is the budget for the implementation of education from the center for education in the regions, which in turn is the ability of the regions to be able to allocate and manage so that the budget is right on target use up to the level of each education unit. The budget allocation for School Operational Assistance (BOS) is regularly disbursed by the central government, and the amount varies, of course, to facilitate school operations as an organizer for extension of the Government and Local Government. The reason for the success or failure of the implementation of education in Bima Regency depends on the attention of the Government and Local Government, as well as schools in managing the budget that has been allocated for education. One of them is through the allocation of school operational assistance funds that are intended for the delivery of education in educational units.

The implementation of the education budget through the allocation of school operational assistance funds should be right on target. The situation in the field shows that the operational budget for the provision of education in the education unit relies solely on the budget that comes from school operational assistance funds, which are disbursed regularly by the government with details of being disbursed four times a year. This is in accordance with the nomenclature of the Regulation of the Minister of 
Education and Culture of the Republic of Indonesia Number 3 of 2019 concerning Technical Instructions for Regular School Operational Assistance Article 4. The structure of school operational assistance funds through deliberations on School Activities and Budget Plans to the number of funding costs through the process. The structure of the preparation of the School Activity Plan and Budget is derived from our analysis of the needs of schools in 1 year, including involving schools and committees. The disbursement model is carried out by the government to school accounts and divided by 4 quarters with the amount of disbursement of school operational assistance funds of $20 \%, 40 \%, 20 \%, 20 \%$.

In relation to the implementation of sports physical education for operations and the purchase of educational facilities in education units, it is taken from school operational assistance funds, but the application model also uses a priority scale of budget allocations after the government has disbursed the budget. Proposals for sports and health education activities are carried out by teachers and processing is carried out through a priority scale of facility procurement allocated from the budget. Including the additional assignment of teachers to become coaches/coaches in extracurricular activities in preparation for student-level competitions is also allocated through the school operational assistance budget. Based on the existing regulations, the flow of budget used for school operational assistance funds is based on the School Activity Plan and Budget, which involves various elements such as the principal, representatives of parents (committees), subject teachers, which are then approved by the principal and endorsed by Local Education Office. The aim is to provide understanding to each principal in the education unit that the percentage of use of the education administration budget is expected to be in accordance with the needs of teacher planning at the time of deliberation to prepare the School Activity and Budget Plan, thus the budget allocation for operational education units is right on target for needs; teaching and learning activities for physical education, sports, and health providers. Policies for Funding Teachers in Education Practice.

\subsection{Policy on Teacher Financing of Education Administration}

The implementation of education in the education unit of Kabupaten Bima is not only a large budget allocation, but the quality of education in Kabupaten Bima is able to be realized through achievement and competing with other areas of education that have developed and are advanced. Based on the results of focus group discussions with various stakeholders consisting of the Education Office, DPRD, education councils, teacher professional organizations, supervisors, teachers, and academics. The implementation of education needs high enthusiasm (ideal). Education budget financing has been described in Law Number 20 of 2003; the mandate of the law also states that education funding is taken at least $20 \%$ of the APBN and 20\% of the APBD. In 2019 the education budget allocation of more than $20 \%$ of the Bima Regency APBD, should have been calculated by the technical sector, managed by 3 Section Heads, the absorption of the education budget in Bima Regency is only $0.3 \%$ of the education budget, for the education budget actually depends on management, finance, not a matter of big and small budget.

The education budget allocation at the Bima District Education Office is used for the office administration service program Rp. 11,512,000,000, Rp. 431,000,000 for apparatus facility and infrastructure improvement program, Rp. 544,500,000, apparatus capacity building program Rp. 995.7650.00, program to increase the development of performance and financial achievement reporting system Rp. 360,100,000, early childhood education program $\mathrm{Rp}$. $1,346,571,000$, a compulsory education program for 12 years of Rp. .118,064,651,000, non-formal education program Rp. 18,539,146,000, program to improve the quality of educators and education personnel $\mathrm{Rp}$. $3,939,215,000$, program to improve sports facilities and infrastructure Rp. , development programs and youth policy harmonization Rp. 1,114,000,000. Then the UPT DIKMEN and PK-PLK BIMA in 2019 allocated an education budget for SMA / SMK amounting to Rp. $1,245,448,249$, through a budget allocation in the office administration service program Rp. 439,604,734, and the apparatus capacity building program amounting to $\mathrm{Rp}$. $12,000,000$. The budget allocation figures that have been carried out by the Department of Education and Culture and the UPT for DIKMEN Services and PK-PLK BIMA in 2019 have very large differences between the budget allocations for the office administration service program and the budget allocation for the quality improvement program for educators and education personnel (HR). The situation in the Dinas Dikbudpora is not much different from the situation in the UPT DIKMEN and PK-PLK BIMA, the budget allocation for the office administration service program is greater than the budget allocation for the apparatus capacity building program (SDM), seeing the amount of education budget allocation figures by the Regional Government of Bima Regency in 2016, 2017, 2018, and 2019. With the budget allocation that has increased many times over $100 \%$, it is certain that the education development of Bima Regency gets special attention from the Regional Government, seeing the urgency of education development in Kabupaten Bima, it gives priority in terms of budget allocation for financing education delivery.

Percentage of the education budget allocation in the Bima District Education Office is used for the office administration service program $69 \%$, the apparatus facility, and infrastructure improvement program $0 \%$, the 
apparatus discipline improvement program Rp. $0 \%$, program to increase the capacity of apparatus resources $0 \%$, program to increase the development of a performance and financial achievement reporting system $0 \%$, early childhood education programs $1 \% \quad 00$, compulsory basic education programs 12 years $7 \%$, non-formal education programs $11 \% 2 \%$ improvement program for the quality of educators and education personnel, 8\% improvement program for sports facilities and infrastructure, $1 \%$ sports coaching and socialization program, $1 \%$ youth policy development and harmonization program. In terms of the percentage of funding for sports and health education providers is more dominant in the sports facilities and infrastructure improvement program $8 \%$, while the amount of the budget allocation for improving the quality of education is generally $2 \%$, which includes the quality of sports and health physical education. This means that the budget allocation for the implementation of education in Bima Regency related to improving the quality of education and sports facilities and infrastructure is only $10 \%$ of the $100 \%$ budget allocation at the Education Office. Meanwhile, $90 \%$ of the education budget allocation is more focused on office administration affairs and other needs in the Bima District Education Office. So that the field findings show that the implementation of education at the Education Unit level in Bima District only relies on school operational assistance funds, while the source of the budget from the Regional Government for education is more allocated to the development of classroom infrastructure in education units and office needs. The role of the BPP / Committee (community) is only a representation of the representative organizations of parents of students, while there is nothing to help with operational costs. Likewise, the private sector around the Education Unit in Bima Regency is only a spectator, there is no contribution to help the operational costs of providing education in the Education Unit. In terms of quantity, the condition of implementation in Bima Regency is not as good as in other areas such as neighboring Bima Regency, namely Bima City, even though the area in 2002 was separated from Bima Regency. However, the delivery of education and the quality of education is better than in Bima Regency. This condition is inseparable from the process, namely the management of budget allocations that are right on target for the delivery of education in Bima Regency which has not been realized. For optimal budget allocation, the amount of the budget must be proportional to both the cost of strengthening human resources and the budget allocation for educational facilities in Bima Regency. Of course, optimizing the budget allocation for the implementation of sports and health physical education will certainly be realized properly in the context of increasing human resources, facilities for providing sports and health physical education for teaching and learning activities in educational units. Funding can help in responding to various needs in educational units because the quality of education delivery depends on the funding input factor to maximize all existing components of implementation.



Figure 4. Expenditure percentage of Bima Dikbudpora office

\section{Discussion}

Over the past 15 years, Indonesia has implemented major policy reforms to improve education. These include a constitutional mandate to spend 20 percent of the national budget on education, decentralize some education sector functions to District and School levels, and implement the Teacher Law in 2005. The government has also increased resources to schools with the School Operations Assistance Program. Grants (School Operational Assistance, or BOS) and supports parents enrolling their children in school through the Word Bank Indonesia Smart Program (Program Indonesia Pintar, or PIP) [17]. Financing education is considered to be one of the main problems in India, especially in the poor, marginalized, and economically weaker communities. When individuals are involved in minority work and experience financial problems, they naturally face obstacles in meeting financial education requirements. The main aspects that have been taken into account in this study are, the structure of education in India, the importance of the education budget, how to finance education, and the factors that identify the basic needs of education financing (Kapur, 2019) [18].

Education has become a space consideration for the modern economy and the backbone for the prosperity of every nation, there is a huge push on a global scale to improve the quality of education that the state provides to its citizens. The best performing education systems have shown that the quality of teachers and improving the social status of teachers are prerequisites for improving the quality of education received by citizens of a country 
(Malik, 2018) [19]. Regarding education policies that look at the effectiveness of budget use in primary schools found that implementing active physical education policies at the primary school level can have little impact on the level of physical activity in the population and have good potential for reducing BMI and reducing the possibility of health problems is associated with obesity in children of primary school age for more than 10 years (Barrett et al, 2015) [20]. That the initial stage of the capital budgeting process is being followed in schools, but its implementation has at least followed suit, which is supported by the proportion of participants indicating that they usually divert funds, the presence of stuck and unemployed projects in schools, and indications that modern capital budgeting appraisal techniques are not highly applied (Gilbert \& Ambrose, 2013) [21].

The budget allocation for the implementation of sports physical education must be useful in strengthening human resources, both strengthening the human resources (internal) of the Education Office as education providers at the Bima Regency level, and (externally) increasing human resources in Bima Regency as strengthening the understanding capacity of the unit organizer level. Education supported by appropriate budget allocations for infrastructure based on the provision of facilities for the provision of physical education in accordance with the changing times. First, ensure the education budget for improving human resources, both strengthening the understanding (ideal) of technical personnel in various fields in the Education Office through the Head of Fields and Section Heads to take part in training programs for improving human resources in the Region and National (internal). Meanwhile, the budget allocation for human resource development (external) is allocated for activities to strengthen school principals, teachers, and students through innovation activities on a contextual basis through mapping of urgent needs that encourage accelerated improvement in the quality of education in accordance with the National Education Standards determined by Central government. As well as carrying out various activities in the form of reasoning (thinking), and skills (skills). Apart from the frequency for training, workshops, seminars, MGMP, it will continue to be improved through the existing activity programs at the Bima District Education Office.
Second, allocate a budget for infrastructure in the context of operational support for technical personnel of the Education Office in carrying out various innovative training activities, competitions at the District, Regency, Provincial, National, and International levels. Another thing that is right on target budget allocation for infrastructure based on the procurement of facilities and infrastructure is to ensure that education delivery facilities are in accordance with the changing times. If the allocation of a large education budget is not optimal, then it will not be maximally used to encourage improvements in education delivery in Bima. The implementation of education requires a large amount of effort and budget allocation based on legislation, the budget does not only come from the government. However, it is necessary to involve a third party as a source of funding for the implementation of education, the third party comes from the community to support various training activities as well as various competition activities held by the Education Office and by credible institutions such as universities. The purpose of how the education system is integrated into development through budget allocations that are clearly sourced from the government and involve other parties as a source of operational funding for the delivery of education in education units, as well as various other activities organized by the Regional Government through the Education Office and supported directly by the community as sponsors. So far, the understanding of public officials from the Education Office regarding the direction of education in Kabupaten Bima still revolves around the budget allocation for prioritized office administration service programs and classroom infrastructure, but for programs to improve the quality of educators and education personnel, it has not been prioritized. Of course, our common hope, including what is found in this research, can provide constructive information and references in fixing the budget allocation system for the implementation of education in Bima Regency, so that optimizing the use of the education budget in the future is focused on programs to improve educators and educational personnel, as well as programs to improve the implementation facilities. education which is a priority program to be built in each Education Unit in Bima Regency. 




Figure 5. Political Will Policy System with Communication Approach, Value, Trust, Authority.

All the discussions that have been conveyed above will be well realized if the political will as a public policy on the implementation of sports and health physical education, building a good bureaucracy, superior teacher human resources, optimizing the use of budgets, and facilities and infrastructure which are fulfilled in the education unit. However, for researchers in implementing public policies in the physical education system, sports, and health, it is also necessary to build a communication system (communication), a system of authority (power), a system of trust (trust), a system of values (values). In line with this Supriadi (2011) [20] the results of his research show the following. First, the quality of communication provides sufficient support in implementing school policies. The expanded form of communication appears to be careful, attractive, accurate, to the point, open and religious, but firm. Second, the quality of available resources is sufficient to support the implementation of school policies. Third, the quality of the executive's attitude provides sufficient support. Fourth, the quality of the bureaucratic structure, the use of references, and resources provide sufficient support.

A communication system (communication). Building a system with communication provides opportunities for the implementation of physical education, sports, and health in educational units to run optimally. Communication is the main key in dealing with the issue of education delivery because communication will provide opportunities for policymakers and stakeholders to unify perceptions about how to build a conducive implementation of sports and health physical education in Bima Regency. Communication will open a positive frame of mind between policymakers and policy implementers in the implementation of physical education, building communication to minimize the deadlock in thinking and acting in deciding a policy for the public interest in the implementation of sports and health physical education. Building good communication will provide opportunities for success in building education in Bima Regency, because the issue of education delivery is a common problem, but it is emphasized on education policymakers through the Education Office. The Education Office and education unit must be able to build effective communication with all parties so that the issue of education delivery can result in clear dialogue with the community. So that through this dialogue forum, it will be able to build healthy communication that creates an attitude of having a shared education in Bima Regency, thus in the future policymakers and the community will have a contribution to jointly endeavor to advance the implementation of physical education.

Authority System (power). The education office and education unit have the authority (power) to determine the direction of education in Bima Regency and the education unit, this authority has been attached to and guaranteed by the constitution to ensure that education is running or not. This authority is also able to carry out evaluations as steps to improve the conditions for the provision of education in Bima Regency and education units. If this authority is able to be implemented properly, it will have a positive impact on improving the implementation of education in Bima Regency, which includes the implementation of sports physical education, as well as issuing innovative policies contained in the road map for the direction of education development policies. The authority of the Education Office and the education unit is through policy alignments to support the implementation of physical education through direct support, building a transparent, credible, and accountable bureaucracy system. The road map is a strategic document for planning guidance to implement policy strategies that are displayed on the direction of education, especially the bureaucratic system, human resources for PJOK, targeted budget allocation for PJOK, and ensuring that the facilities and infrastructure are met with all material for implementing PJOK in the unit. education. In realizing all that requires conscious and planned efforts through the authority of the Education Office and the education unit as the authorities that have the authority to manage the implementation of physical education. 
Trust System. If all efforts and efforts are made through communication and authority exercised by education Providers in Bima Regency to support $100 \%$ of the implementation of physical education can be fulfilled in the education unit, there is great hope that it will get direct support and trust from the community. So that the attention of policymakers to continue to build an image through programs that encourage the acceleration of improvement in education delivery. Because trust is a positive spirit that the other party will not take opportunistic actions either through speech, behavior, or decisions. Building trust is to foster an attitude of optimism in improving the education delivery system, so as to provide a confident attitude that the implementation of physical education is capable of realizing both academic and non-academic achievements. Through the authority possessed by the administration of education, it will be possible to provide direct support for programs to accelerate the improvement of the quality of teacher human resources through various training activities and similar activities. Apart from proper budget support and adequate facilities and infrastructure in the education unit, the implementation of physical education can compete with other regions in NTB Province.

Value System (values). The impact of policies in the implementation of physical education is in the form of values if the policy is always in favor of the public interest, the value obtained is the trust of all parties, as well as appreciation from the community in the implementation of physical education in educational units. However, if the value built by education providers is in the form of policies that only benefit leaders/superiors, then that image is only temporary for what is done by education providers. If the system built produces a value of appreciation from the leadership and public appreciation, then both are rewarded (reward) for the achievements made by education providers, in this case, the Education Office and education units. Such appreciation is a manifestation of what is done in various program activities carried out by education providers, both programs to build an accountable system, and even more so for programs that encourage increased human resources, budget support, and assistance with facilities and infrastructure for the provision of physical education. sport and health, giving birth to a unique policy breakthrough towards improving the system for providing physical education, sports, and health in schools, for example, the availability of facilities and infrastructure, and innovation program to improve the quality of teachers. This can be realized technically through the preparation of programs and budget allocations from the Education Office and education units for the implementation of physical education. So that the value of public trust in the implementation of education, directly the education office and education unit get appreciation and recognition from the community

\section{Conclusions and Limitations}

The education budget allocated from the regional income and expenditure budget of Bima Regency amounts to Rp. $174,113,270,000.00$. For the SMA / SMK level, the budget allocation for education through the NTB Provincial DIKBUD through the UPT Dikmen Services and PK-PLK Bima in 2019 education budget allocation is Rp. 1,245,448,249. The budget for education in Kabupaten Bima exceeds the minimum limit of $20 \%$ which is allocated from the regional income and expenditure budget based on the constitutional order. The operational administration of education at the Education Unit level in Bima District only relies on school operational assistance funds, because the budget allocation from the government is dominant, namely class building infrastructure and the procurement of office administration for the Bima District Education Office. The use of the budget has not been optimal for programs to improve the quality of human resources, because only $0.3 \%$ is used from the education budget. Meanwhile, for improving the quality of education by $2 \%$ and the program for improving facilities and infrastructure for $8 \%$, furthermore, funding from the community to help with school operational costs is not carried out. Schools independently organize education from school operational assistance funds, both regarding the provision of facilities and other activities in the school. Building-integrated education funding has not been able to be realized, because the government, schools, and the community have not maximally worked together in realizing the delivery of quality sports and health physical education.

Building a policy system regarding the financing of education, it is necessary to start building the integrity of policymakers, building a budget management system that is right on target, both strengthening the human resources (internal) of the Education Office as education providers at the Bima Regency level, and (externally) increasing program activities that encourage the quality of teacher competence in Bima Regency as a strengthening of understanding capacity at the level of education units. Supported by appropriate budget allocations for infrastructure based on the provision of educational facilities in accordance with the changing times, all the discussions that have been conveyed above will be well realized if the political will as a public policy on the implementation of sports and health physical education, building a good bureaucracy, superior teacher human resources, optimizing the use of budgets, and facilities and infrastructure which are fulfilled in the education unit. However, for researchers in implementing public policies in the physical education system, sports, and health, it is necessary to also build a communication system (communication), a system of authority (power), a system of trust (trust), a system of values (values). 


\section{REFERENCES}

[1] Antoni V, Clara F, A. A. Z. (2016). The Privatization of Education: A Political Economy of Global Education Reform. In New Labour and Secondary Education, 19942010. https://doi.org/10.1057/9781137076328_6

[2] Avourdiadou, S., \& Theodorakis, N. D. (2014). The development of loyalty among novice and experienced customers of sport and fitness centres. Sport Management Review, 17(4), 419-431.https://doi.org/10.1016/j.smr.2014. 02.001

[3] Barrett, J. L., Gortmaker, S. L., Long, M. W., Ward, Z. J., Resch, S. C., Moodie, M. L., Carter, R., Sacks, G., Swinburn, B. A., Wang, Y. C., \& Cradock, A. L. (2015). "Cost Effectiveness of an Elementary School Active Physical Education Policy." American Journal of Preventive Medicine, 49(1), 148-159. https://doi.org/10.1016/j.amepre. 2015.02.005

[4] Bellei, C., \& Orellana, V. (2015). What does "education privati sation" mean? Conceptual dis cussion and empirical review of Latin American cases. Education Support Program Working Paper 62. London, UK: OSF.

[5] Bellinger, A., Terway, A., \& Burnett, N. (2016). The Education Commission background paper: Innovative financing recommendations. http://report.educationcommis sion.org/resource-materials/\#

[6] Gilbert, N., \& Ambrose, J. (2013). "Capital Budgeting Procedures and Practices in Public Secondary Schoolsin Kenya: The Case Study of Meru North District." International Journal of Humanities and Social Science, $3(21), 126-134$.

[7] Herdjiono, I., \& Damanik. (2016). Pengaruh Financial Atti Tude, Financial Knowledge, Parental Income Terhadap Financial Management Behavior. Manajemen Teori Dan Terapan, 1(3), 226-241.

[8] Kapur, R. (2019). Pioneering Ways of Financing Education. $5,1-8$.
[9] Malik, R. S. (2018). Educational Challenges In $21 \mathrm{St}$ Century and Sustainable Development. Journal of Sustainable Development Education and Research. JSDER Vol. 2, No.1, 2018, Pp. 9-20, 2(1), 9-20.

[10] Ndayisenga, J., \& Tomoliyus. (2019). Effect of service quality and rates on satisfaction and loyalty of customer behavior at fitness. International Journal of Human Movement and Sports Sciences, 7(2), 25-32. https://doi.org/10.13189/saj.2019.070202

[11] Nwafukwa, P. . O. (2015). Financial Management Skills Required Of Principals For The Implementation Of The Universal Basic Education Programme In Junior Secondary Schools In Ebonyi State Of Nigeria. Journal of Chemical Information and Modeling, 53(9), 1689-1699. https://doi.org/10.1017/CBO9781107415324.004

[12] Ramba, H., \& Nur, S. (2015). Budget Management Performance Based On The Department Of Education Regional Konawe. International Journal of Scientific \& Technology Research, 4(3), 241-252.

[13] Ramdhani, A., \& Ramdhani, M. A. (2017). Konsep Umum Pelaksanaan Kebijakan Publik. Jurnal Publik, 1-12. https://doi.org/10.1109/ICMENS.2005.96

[14] Seiter, M., \& Seiter, M. (2016). Making Public Policy Work for Physical Education Making Public Policy Work for Physical Education. 3084(March). https://doi.org/10.1080/0 7303084.1983.10630498

[15] Supriadi, A. (2011). Analisis Prakondisi Implementasi Kebijakan Peningkatan Kompetensi Guru. Jurnal Pendidikan Dan Pembelajaran (JPP), 18(1), 36-46.

[16] World bank. (2019). http://siteresources.worldbank.org/INT LL/Resources/Lifelong-Learning-in-the-Global-Knowledge -Economy/chapter4.pdf.

[17] Word bank. (2014). Spending More or Spending Better: Improving Education Financing in Indonesia. https://www.worldbank.org/en/search?q=education+in+ind onesia. 